\title{
Article \\ Boron Removal from Desalinated Seawater for Irrigation with an On-Farm Reverse Osmosis System in Southeastern Spain
}

\author{
Alberto Imbernón-Mulero ${ }^{1} \mathbb{D}$, Belén Gallego-Elvira ${ }^{1, * \mathbb{D}}$, Victoriano Martínez-Alvarez ${ }^{1} \mathbb{D}$,

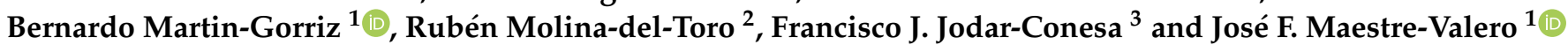 \\ 1 Department of Agricultural Engineering, Technical University of Cartagena, Paseo Alfonso XIII 48, \\ 30203 Cartagena, Spain; alberto.imbernon@edu.upct.es (A.I.-M.); victoriano.martinez@upct.es (V.M.-A.); \\ b.martin@upct.es (B.M.-G.); josef.maestre@upct.es (J.F.M.-V.) \\ 2 ECOHIDRO Agua y Medio Ambiente, Polígono Industrial El Arreaque, 30170 Mula, Spain; \\ ruben.molina@ecohidro.es \\ 3 Agrícola Conesa Marín S.L., Paraje Los Bastidas, 42, 30700 Torre Pacheco, Spain; franconesa@live.com \\ * Correspondence: belen.gallego@upct.es
}

check for updates

Citation: Imbernón-Mulero, A.; Gallego-Elvira, B.; Martínez-Alvarez, V.; Martin-Gorriz, B.;

Molina-del-Toro, R.; Jodar-Conesa, F.J.; Maestre-Valero, J.F. Boron Removal from Desalinated Seawater for Irrigation with an On-Farm Reverse Osmosis System in Southeastern Spain. Agronomy 2022, 12, 611. https://doi.org/10.3390/ agronomy12030611

Academic Editors: Anita Ierna and Salvatore Camposeo

Received: 10 January 2022

Accepted: 27 February 2022

Published: 28 February 2022

Publisher's Note: MDPI stays neutral with regard to jurisdictional claims in published maps and institutional affiliations.

Copyright: (C) 2022 by the authors. Licensee MDPI, Basel, Switzerland. This article is an open access article distributed under the terms and conditions of the Creative Commons Attribution (CC BY) license (https:// creativecommons.org/licenses/by/ $4.0 /)$.

\begin{abstract}
Seawater desalination can provide water for irrigation in coastal regions where freshwater resources are scarce. Reverse osmosis $(\mathrm{RO})$ is the most common technique to obtain desalinated seawater (DSW) worldwide. However, using DSW for irrigation may pose an agronomic risk as RO permeates have a boron concentration above the phytotoxicity thresholds of some sensitive crops, such as woody crops ( 0.5 to $1.0 \mathrm{mg} / \mathrm{L})$. In this study, an on-farm RO system designed to reduce the boron concentration of DSW was evaluated from a technical and economic perspective. The impact of variations in the operating parameters feed water temperature, pressure, and $\mathrm{pH}$, on the boron reduction process was assessed. The results showed that boron rejections close to $99 \%$ can be obtained by increasing the feed water $\mathrm{pH}$ to 11 with an operating pressure of 10 bar. Looking at the affordability of the system, a total production cost of $1.076 \mathrm{EUR} / \mathrm{m}^{3}$ was estimated for the $1.1 \mathrm{~m}^{3} / \mathrm{h}$ on-farm system used in the trial. However, this cost is expected to decrease to $0.307 \mathrm{EUR} / \mathrm{m}^{3}$ for a commercial RO plant $\left(42 \mathrm{~m}^{3} / \mathrm{h}\right)$, highlighting the importance of the scale factor. Our results provide novel guidance on the feasibility of implementing on-farm boron removal RO systems, when DSW is provided by coastal plants with boron concentrations above the crop tolerance.
\end{abstract}

Keywords: agricultural sustainability; non-conventional water resources; boron phytotoxicity; economic analysis

\section{Introduction}

Seawater desalination provides a steady water supply that overcomes climatological and hydrological constraints and mitigates drought risks in coastal regions where freshwater resources are scarce [1,2]. Spanish water policy has been oriented towards seawater desalination as an alternative to other water supply options since the beginning of the 21st century [3]. In Spain, desalinated seawater (DSW) is hence being increasingly seen as a viable option to sustain both domestic and agricultural needs, since it is considered an inexhaustible resource $[1,4]$.

Globally, 40 million $\mathrm{m}^{3}$ / day ( 1 million $\mathrm{m}^{3}$ /day in Spain) of DSW are currently produced with reverse osmosis (RO) plants [1]. With RO, which is the most common desalination technique, salts are removed by supplying pressure on the feed water that permeates through a semipermeable membrane [5-7]. One of the main limiting factors for its use in irrigation, in addition to the high associated energy consumption and production costs $[1,2,4,8]$, is the high boron concentration of DSW (around $0.5-1.0 \mathrm{mg} / \mathrm{L}$, depending on the treatment in the RO plant) that may imply toxicity risks and harmful effects for crop productivity in the medium term [4]. In Spain, the maximum boron concentration allowed by law in water for human consumption is $1 \mathrm{mg} / \mathrm{L}$ (Royal Decree 140/2003). In the absence 
of a specific regulation, the same value is also adopted for irrigation water, unlike other countries such as Israel where the maximum boron concentration is below $0.5 \mathrm{mg} / \mathrm{L}$, to prevent phytotoxicity issues [9].

Boron is an essential nutrient involved in many physiological processes $[6,10]$ with its main function being to maintain the structure and the correct behavior of the cell wall. Moreover, it has different roles in the cytoskeleton and membrane and participates in the metabolism of nucleic acids, the synthesis of proteins, and hormonal regulation [11]. One unique characteristic that differentiates boron from other nutrients is its chargeless form of boric acid $\left(\mathrm{H}_{3} \mathrm{BO}_{3}\right)$, which exists at a physiological $\mathrm{pH}$ [11] and allows the small neutral solutes to have a high permeability through the lipid bilayer of cellular membranes driven by the transpiration process [12]. Boron usually accumulates in mature leaves, which could lead to chlorotic and necrotic patches when the absorbed boron exceeds the plant toxicity threshold [10]. The latter fosters the inhibition of photosynthesis and a reduction in stomatal conductance [13], which may in turn lead to negative crop productivity effects. Considering this hazard, the boron toxicity threshold in irrigation water for most woody crops has been set at between 0.5 and $0.7 \mathrm{mg} / \mathrm{L}[9,14]$. In southeast of Spain, some 47,000 ha of woody crops may be irrigated with DSW, at an average rate of about $2500 \mathrm{~m}^{3} /$ ha $(74.7 \%$ citrus, $15.4 \%$ almonds, $6.2 \%$ stone fruit trees, $3.6 \%$ olives, and $0.1 \%$ vines) [7]. In the medium-long term, boron accumulation in the mature tissues may pose a toxicity risk and compromise harvests [4].

Reductions of potentially harmful boron concentrations in the DSW should be performed prior to using DSW for irrigation, particularly in areas where water blending with other resources with lower boron concentrations is not an option [3,4,11]. Boron reduction to non-hazardous levels is technically feasible at both coastal DSW and on-farm RO plants. In fact, specific membranes are already being used to increase the boron reduction effectiveness and they are able to reach high rejection values $[5,15,16]$. However, different parameters involved in the $\mathrm{RO}$ process, mainly the type of membrane, the inlet water temperature, the water flow pressure, and the $\mathrm{pH}$, may condition the boron reduction efficiency [16-18].

Concerning water $\mathrm{pH}$, at typical DSW $\mathrm{pH}$ levels $(\mathrm{pH}=8)$ boron mostly appears as $\mathrm{H}_{3} \mathrm{BO}_{3}(>90 \%)$ [19] and the capacity of the $\mathrm{RO}$ membranes to reject boron is very limited, as $\mathrm{H}_{3} \mathrm{BO}_{3}$ easily permeates through them. Nevertheless, $\mathrm{H}_{3} \mathrm{BO}_{3}$ is a weak acid with a $\mathrm{pK}_{\mathrm{a}}$ of 9.2 that ionizes to a significant extent at $\mathrm{pH}$ higher than $9[17,20]$ and behaves as a Lewis acid $\left(\mathrm{H}_{3} \mathrm{BO}_{3}+\mathrm{H}_{2} \mathrm{O} \leftrightarrow \mathrm{B}(\mathrm{OH})_{4}{ }^{-}+\mathrm{H}^{+}\right)[19]$, resulting in a boron structure $\left(\mathrm{B}(\mathrm{OH})_{4}{ }^{-}\right)$that is easier to retain by $\mathrm{RO}$ membranes at increasing $\mathrm{pH}$ values. In fact, it has been reported that almost all boron content can be effectively removed when the feed water has a $\mathrm{pH}$ close to $11[5,6,12,15,20]$. Nevertheless, concentration polarization and fouling, which are endemic problems in $\mathrm{RO}$ process, especially occur if a strong alkalinization is performed in order to remove boron satisfactorily $[2,8,21]$, due to the formation and precipitation of $\mathrm{CaCO}_{3}$. This could jeopardize the rejection capacity and efficiency of the RO membranes $[8,22,23]$.

With regards to water temperature, higher temperatures increase the transfer of salts through the RO membranes, since the solubility of salts usually increases with temperature $[6,16]$. As the temperature rises, the average kinetic energy of the molecules that form the solution also increases. This increase in kinetic energy enables the solvent molecules to more effectively damage the solute molecules that are held together by intermolecular attractions [24,25]. Moreover, it has been observed that the permeate flow may increase up to $4 \%[26,27]$, with a boron reduction between 1 and $5 \%$ for each degree increment of temperature [27-29]. Additionally, such an increase in water flow passing through the membranes favors the reduction of the specific energy of the process [16].

Last but not least, an increase in the pressure of the system enhances the rejection of salts, including boron [30]. Some research has observed increases in boron rejections of up to $12 \%$ when the pressure is augmented from 16 to 35 bar [31], of up to $21 \%$ from 12.5 to 16.2 bar [32] and of up to $10 \%$ from 41.3 to 48.2 bar [33]. Moreover, it has been shown that the transfer of salts throughout a semipermeable membrane is a function of the 
concentration gradient and hence, a rise in pressure produces a flow rate increase of the water inlet [30,31], but keeps the entrance of dissolved salts constant [16], which results in a higher quality permeate $[15,19,31]$.

To the best of our knowledge, boron reduction studies have been mainly performed at laboratory scale and/or using working pressures of between 40 and 60 bar, similar to those used in coastal seawater desalination plants $[6,10,27,29,31]$. In RO plants, boron removal is usually performed by a two-pass $\mathrm{RO}$ system or by a combination of the RO process with other methods such as ion exchange resins or nanofiltration, among others $[15,21,34,35]$. Under these high-pressure conditions, the inlet water does not require to be highly alkalized to easily reduce boron up to $0.5 \mathrm{mg} / \mathrm{L}$. However, coastal desalination plants in Spain are not implementing these technologies to further reduce boron, mainly because boron concentrations up to $1 \mathrm{mg} / \mathrm{L}$ are legal, as stated above, and also due to the fact that it would imply an increase of costs. The novelty of this work is to explore the viability of performing boron removal with an on-farm $\mathrm{RO}$ system with much lower pressures but increasing the $\mathrm{pH}$, in order to achieve a boron concentration below the threshold of sensitive crops. In particular, in this study, the performance of an on-farm RO boron reduction system is assessed at pressures from 8 to $10 \mathrm{bar}$, with $\mathrm{pH}$ values between 8.7 and 11 , and at temperatures from 15 to $21^{\circ} \mathrm{C}$. Based on the trial results, the technical and economic viability of this novel option for intensive agriculture in areas irrigated with DSW is assessed and recommendations are given.

\section{Materials and Methods}

\subsection{Experiment Site and Desalinated Seawater}

The experimental work was carried out between October 2020 and April 2021 at a commercial farm located in Torre Pacheco, Murcia, Spain $\left(37^{\circ} 47^{\prime} 30^{\prime \prime} \mathrm{N}\right.$; $1^{\circ} 03^{\prime} 85^{\prime \prime} \mathrm{W}$; $30 \mathrm{~m}$ above sea level). The DSW for the trial came from the coastal desalination plant of Escombreras, located in Cartagena (southeast of Spain). Table 1 shows the physical and chemical properties of the DSW supplied by the plant.

Table 1. Values of physical and chemical properties of the desalinated seawater supplied by the Escombreras desalination plant.

\begin{tabular}{|c|c|c|c|c|c|c|c|c|}
\hline Date & $\begin{array}{c}\text { Temp } \\
\left({ }^{\circ} \mathrm{C}\right)\end{array}$ & $\mathrm{pH}$ & $\begin{array}{c}C E \\
(\mathrm{dS} / \mathrm{m})\end{array}$ & $\begin{array}{c}\mathrm{Ca}^{2+} \\
(\mathrm{mg} / \mathrm{L})\end{array}$ & $\begin{array}{c}\mathrm{Mg}^{2+} \\
(\mathrm{mg} / \mathrm{L})\end{array}$ & $\begin{array}{c}\mathrm{Cl}^{-} \\
(\mathrm{mg} / \mathrm{L})\end{array}$ & $\begin{array}{c}\mathrm{Na}^{+} \\
(\mathrm{mg} / \mathrm{L})\end{array}$ & $\begin{array}{c}\text { B } \\
(\mathrm{mg} / \mathrm{L})\end{array}$ \\
\hline April 2021 & $15 \pm 0.5$ & $8.71 \pm 0.13$ & $0.60 \pm 0.06$ & $20.8 \pm 0.7$ & $2.3 \pm 0.1$ & $183.9 \pm 10.2$ & $112.1 \pm 1.1$ & $1.10 \pm 0.02$ \\
\hline February 2021 & $17 \pm 0.5$ & $8.70 \pm 0.05$ & $0.74 \pm 0.12$ & $27.6 \pm 1.1$ & $5.0 \pm 0.1$ & $219.5 \pm 6.8$ & $104.3 \pm 0.7$ & $1.06 \pm 0.01$ \\
\hline October 2020 & $19 \pm 0.5$ & $8.34 \pm 0.36$ & $1.06 \pm 0.07$ & $18.0 \pm 2.6$ & $2.86 \pm 0.1$ & $226.7 \pm 15.1$ & $166.0 \pm 0.9$ & $0.92 \pm 0.01$ \\
\hline October 2020 & $21 \pm 0.5$ & $7.91 \pm 0.15$ & $1.00 \pm 0.03$ & $25.0 \pm 1.0$ & $4.1 \pm 0.1$ & $298.9 \pm 20.5$ & $170.7 \pm 2.2$ & $0.97 \pm 0.01$ \\
\hline Average & - & $8.54 \pm 0.54$ & $0.85 \pm 0.22$ & $22.8 \pm 4.3$ & $3.6 \pm 1.2$ & $232.3 \pm 48.2$ & $138.3 \pm 35$ & $1.01 \pm 0.10$ \\
\hline
\end{tabular}

\subsection{On-Farm Reverse Osmosis Plant}

For the trial, an experimental on-farm RO system (Figure A3) was designed to reduce the boron concentration of DSW and to assess the effect of water temperature, pressure, and $\mathrm{pH}$ on the reduction efficiency. It consisted of: (i) a 2.5-bar feed pump (Grundfos, Model CM1-4, $0.5 \mathrm{~kW}$ ) working at a flowrate of 1.0 to $1.5 \mathrm{~m}^{3} / \mathrm{h}$; (ii) a pre-treatment system, with a zeolite and pyrolusite bed filter ( 250 L capacity), an activated carbon filter (big type, compressed) and a microfilter (big type, extruded polypropylene) to retain particles up to $0.1 \mu \mathrm{m}$; (iii) a pH meter (Burkert, $\mathrm{pH}$ measurement device Model 561686); (iv) a dosing pump (SEKO automatic pump, $2 \mathrm{~L} / \mathrm{h}$ at 7 bar) to regulate the $\mathrm{pH}$ of the feed water with sodium hydroxide ( $\mathrm{NaOH}$ ); (v) a high-pressure pump (Grundfos, Model CR 3-36) to reach 8 to 10 bar; and (vi) six $\mathrm{RO}$ units, placed in series with one inner membrane each. The RO membranes were made of composite polyamide with a low fouling spiral-wound configuration and a $37.2 \mathrm{~m}^{2}$ active area. They both had high salt rejection $(99.7 \%)$ and high-volume recovery. During the operation, the concentrate of the first membrane was recirculated to the next one, reintroducing it as feed. Figure 1 shows the configuration of 
the experimental system and the sampling procedure of the experiment, and Table 2 shows the most relevant characteristics of the membranes.

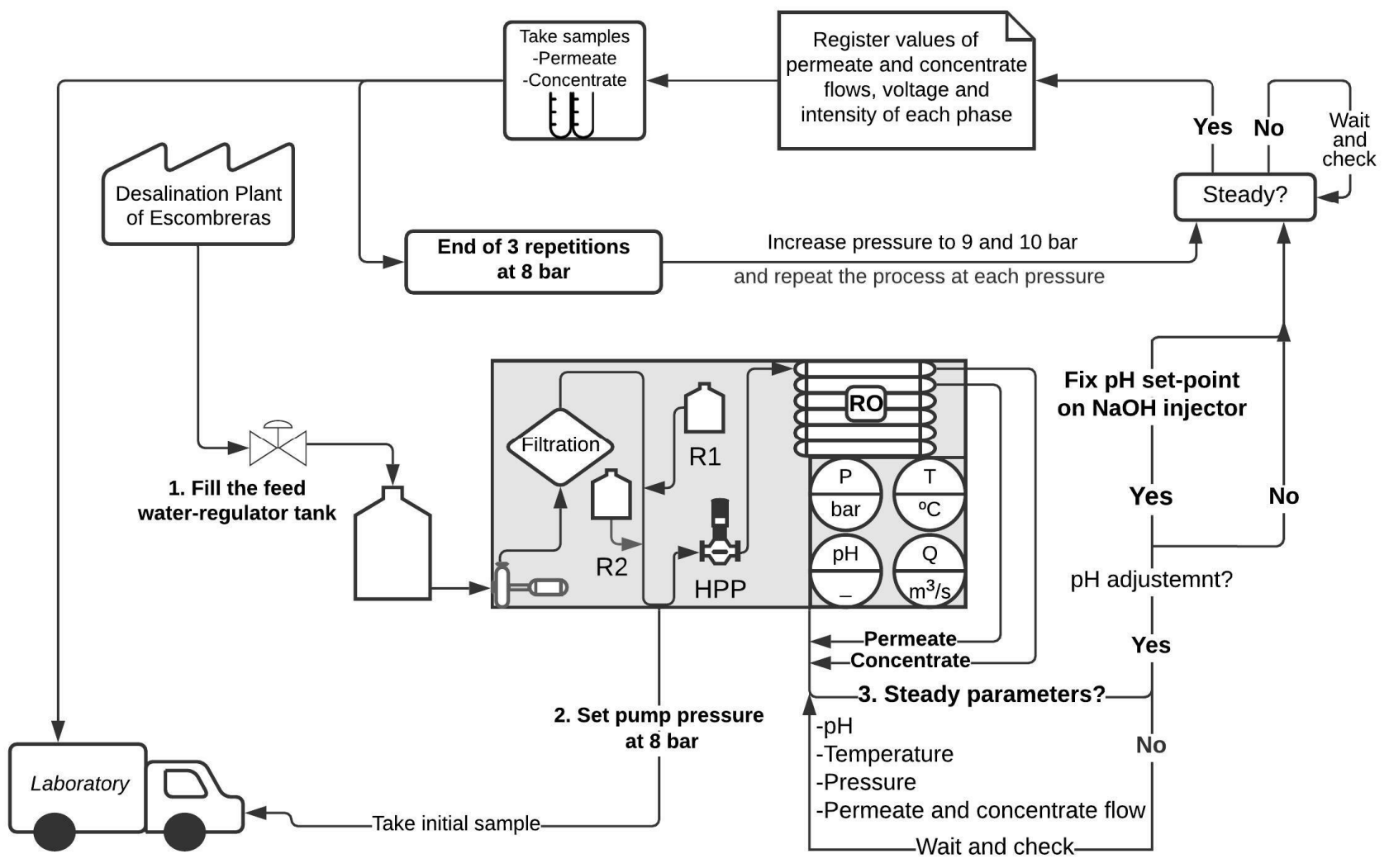

Figure 1. Configuration of the experimental on-farm RO system and sampling procedure of the experiment. HPP: high pressure pump, R1: Antiscalant tank, R2: NaOH tank.

Table 2. Characteristics of the reverse osmosis membranes selected for the trial.

\begin{tabular}{cc}
\hline Characteristics & Membranes \\
\hline Manufacturer & Hydranautics \\
Model & CPA7-LD-4040 \\
Configuration & Low fouling spiral wound \\
Membrane type & Composite polyamide \\
Minimum salt rejection, $\%$ & 99.7 \\
Maximum permeate flow, $\mathrm{m}^{3} / \mathrm{d}$ & 43.5 \\
pH range, continuous (cleaning) & $2-11(1-13)$ \\
Maximum operating temperature & $45^{\circ} \mathrm{C}$ \\
Maximum pressure drop for each element & $0.10 \mathrm{MPa}$ \\
\hline
\end{tabular}

The average treatment capacity of the experimental system was $1.1 \mathrm{~m}^{3} / \mathrm{h}(\mathrm{D} 1)$; this corresponds to an annual production capacity of $7700 \mathrm{~m}^{3} /$ year, which could irrigate one hectare of citrus crop. Additionally, two analogous on-farm $\mathrm{RO}$ systems, with higher feed water flows of $21 \mathrm{~m}^{3} / \mathrm{h}$ (D2) and $42 \mathrm{~m}^{3} / \mathrm{h}$ (D3), were considered for the economic evaluation. They were selected to provide a more realistic scale for the economic analysis. These systems would have an annual production capacity of 147,000 and 294,000 $\mathrm{m}^{3} /$ year, which would allow irrigating 17.5 and 34.6 hectares of citrus crop, respectively.

\subsection{Tests and Treatments}

In order to analyze the effects of the variation of the water temperature on the reduction of boron, the treatments were conducted at $15,17,19$, and $21^{\circ} \mathrm{C}$. At each temperature, the effect of the $\mathrm{pH}$ was evaluated at $\mathrm{pH}=8.7,9.5$, and 11 (namely $\mathrm{pH}$ set-points). The $\mathrm{pH}$ was 
increased by injecting sodium hydroxide into the DSW, as shown in Appendix A. Finally, in order to assess the effect of the pressure, the trials were conducted at 8, 9, and 10 bar. Three repetitions were done for each configuration. Table 3 presents the summary of the tests performed.

Table 3. Tests performed in the trial.

\begin{tabular}{cccc}
\hline Temperatures $\left({ }^{\circ} \mathbf{C}\right)$ & $\mathbf{p H}$ & Treatment & Pressure (bar) \\
\hline & \multirow{2}{*}{$\mathrm{pH}$ set-point $=8.7$} & 1.1 & 8 \\
& & 1.2 & 9 \\
\cline { 2 - 4 } & \multirow{3}{*}{ 15, 17, 19, and 21 } & 1.3 & 10 \\
& $\mathrm{pH}$ set-point $=9.5$ & 2.1 & 8 \\
& & 2.2 & 9 \\
\cline { 2 - 4 } & \multirow{2}{*}{$\mathrm{pH}$ set-point $=11$} & 2.3 & 10 \\
& & 3.1 & 8 \\
& 3.2 & 9 \\
\end{tabular}

\subsection{Ion Reduction}

In order to characterize the effect of the $\mathrm{RO}$ membranes on the reduction of ions in the permeate, samples of the feed water, the permeate of the membranes and the concentrate were taken and analyzed. In each test, one water sample from each water source was collected in glass bottles, transported in an icebox to the laboratory and stored at $5{ }^{\circ} \mathrm{C}$ before being processed for physical and chemical analyses. An inductively coupled plasma (ICP-MS Agilent Technologies, Model 7900, Santa Clara, CA, USA) was used to determine the concentration of $\mathrm{Na}^{+}, \mathrm{K}^{+}, \mathrm{Ca}^{2+}, \mathrm{Mg}^{2+}$, and $\mathrm{B}^{3+}$. Anions $\left(\mathrm{Cl}^{-}, \mathrm{NO}_{3}{ }^{-}, \mathrm{PO}_{4}{ }^{3-}\right.$, and $\left.\mathrm{SO}_{4}{ }^{2-}\right)$ were quantified by ion chromatography with a liquid chromatograph (Thermo Scientific Dionex, Model ICS-2100, Thermo Scientific, Basel, Switzerland). The electrical conductivity of the water (EC) was determined by means of a conductivity instrument GLP-31 (Crison Instruments S.A., Barcelona, Spain). The $\mathrm{pH}$ was measured with a $\mathrm{pH}$-meter GLP-21 (Crison Instruments S.A., Barcelona, Spain). The boron reduction in the permeate was calculated as follows:

$$
\text { Boron reduction }(\%)=\left(1-\frac{\left[B_{\text {permeate }}\right]}{\left[B_{\text {feed water }}\right]}\right) \cdot 100 \text {, }
$$

where $\left[B_{\text {permeate }}\right]$ and $\left[B_{\text {feed water }}\right]$ were the boron concentrations of the permeate and the feed water $(\mathrm{mg} / \mathrm{L})$, respectively.

\subsection{Specific Energy Consumption of the On-Farm Reverse Osmosis System}

In order to determine the energy consumption $\left(E_{\mathrm{c}} ; \mathrm{kW} \cdot \mathrm{h}\right)$ associated to the boron reduction for each test, the current intensity of the electrical panel was measured with a current clamp (TENMA, Model 72-2985) and annotated along with the instantaneous permeate flow at that moment. Additionally, the voltage between phases was registered using a digital multimeter (UNI-I, Model YT33A). Then, $E_{\mathrm{c}}$ and the specific energy consumption $\left(E_{S}\right)$ associated to the boron reduction $\left(\mathrm{kW} \cdot \mathrm{h} / \mathrm{m}^{3}\right)$ were calculated according to the following equations:

$$
\begin{gathered}
E_{C}=\left(I_{R} \cdot V_{N-R}+I_{S} \cdot V_{N-S}+I_{T} \cdot V_{N-T}\right) \cdot t, \\
E_{S}=\frac{I_{R} \cdot V_{N-R}+I_{S} \cdot V_{N-S}+I_{T} \cdot V_{N-T}}{1000 \cdot Q_{\text {Permeate }}},
\end{gathered}
$$


where $I_{R}, I_{S}$, and $I_{T}$ were the current intensity (A), $V_{N-R}, V_{N-S}, V_{N-T}$ were the voltage between the neutral and the phases $R, S$ and $T$, respectively $(V), Q_{\text {permeate }}$ the flow of permeate $\left(\mathrm{m}^{3} / \mathrm{h}\right)$, and $t$ the time (hours).

For the case of the D2 and D3 RO designs, the energy consumption $(\mathrm{kW} \cdot \mathrm{h})$ and the specific energy $\left(\mathrm{kW} \cdot \mathrm{h} / \mathrm{m}^{3}\right)$ were determined according to the manufacturer's instructions and based on both the electricity consumption of the plants and their treatment flows.

\subsection{On-Farm Reverse Osmosis Economic Costs}

Both the fixed and the variable costs were considered in the economic evaluation of the on-farm reduction of boron. The fixed costs included the depreciation costs of the equipment, whereas the variable costs included all the operation costs, i.e., the cost of chemical products and energy used in the operating process, and the maintenance costs of the equipment.

\subsubsection{Depreciation Costs}

The amortization cost was calculated as the annual payment fee, as shown in Equation (4).

$$
C=V_{a d} \cdot\left(\frac{i \cdot(1+i)^{a}}{(1+i)^{a}-1}\right),
$$

where $C$ (EUR/year) was the annual payment fee (EUR), $V_{a d}$ the equipment acquisition value (EUR), $i$ the interest, and $a$ the equipment lifespan (years).

For the calculation, a lifespan of 15 years for the RO equipment was taken into account, which considered $7000 \mathrm{~h}$ of annual operation, and an interest rate of $5 \%$. The acquisition value of this on-farm equipment provided by the manufacturer was 50,046 EUR. Note that this is the cost for the experimental system (D1, $1.1 \mathrm{~m}^{3} / \mathrm{h}$ ). The previously-mentioned more realistic designs with higher permeate flow, D2 $\left(21 \mathrm{~m}^{3} / \mathrm{h}\right)$ and D3 $\left(42 \mathrm{~m}^{3} / \mathrm{h}\right)$ had investment costs of 80,908 EUR and 139,943 EUR, respectively.

\subsubsection{Cost of Reagents}

The volumes of reagents to be injected into the DSW, sodium hydroxide $(\mathrm{NaOH}$; 2.12 EUR/L) and antiscalant (Genesys LF; 7.80 EUR/L) are shown in Appendices A and B.

\subsubsection{Energy Cost}

The energy cost was computed with Equation (2), considering the average energy price $(0.134 \mathrm{EUR} / \mathrm{kW} \cdot \mathrm{h})$ paid during the trial.

\subsubsection{Maintenance Cost}

The maintenance cost considered the spare parts that had to be replaced to avoid malfunction according to the manufacturer's guidelines, and included filters, bearings, o-rings, seals, dispenser maintenance kits and level, $\mathrm{pH}$, and electrical conductivity probes (Table 4). Taking in consideration that some elements needed to be replaced each 1, 2, or 5 years, the costs were calculated annually for the equipment lifespan.

\subsection{Statistical Analysis}

The statistical analysis performed was a weighted analysis of variance (ANOVA) using the statistical software IBM SPSS Statistics v. 21 for Windows, as well as a Shapiro-Wilk test to evaluate the normality of the data and a Tukey's Honestly Significant Difference (HSD) test to check differences among means for significance. Unless otherwise stated, the significance level was $p \leq 0.05$. 
Table 4. Spare parts needed for the three RO systems considered in the study.

\begin{tabular}{ccccc}
\hline D1 or D2 Plants & D3 & Spare Part & $\begin{array}{c}\text { Replacement } \\
\text { Frequency }\end{array}$ & $\begin{array}{c}\text { Quantity } \\
\text { Plant }\end{array}$ \\
\hline- & - & SEKO AKL 603 dosing maintenance kit & 1 year \\
- & - & SEKO TPR 603 dosing maintenance kit & 1 year & 1 \\
- & - & PH probe Seko & 1 year & 1 \\
- & - & CE probe Seko & 1 year & 1 \\
- & - & Level probe Seko & 1 year & 1 \\
TPE 50-530 & TPE 50-540 & 2 pump spare parts kit (breather plug, mechanical seals, and wear rings) & 2 years \\
TPE 50-530 & TPE 50-540 & 2 pump spare parts kit (impeller) & 5 years & 1 \\
CR 20-14 & CR 64-5 & Pump spare parts kit (mechanical seal, gasket kit) & 2 years & 1 \\
CR 20-14 & CR 64-5 & Pump spare parts kit (bearing kit, repair kit) & 5 years & 1 \\
CM 15-3 & CM 40-160 & Pump spare parts kit (mechanical seal, O-rings, repair kit) & 2 years & 1 \\
CM 15-3 & CM 40-160 & Pump spare parts kit (bearing kit) & 5 years & 1 \\
- & - & Microfiltration cartridge 40 “1 micron & 6 months & 12 \\
\hline
\end{tabular}

\section{Results and Discussion}

\subsection{Effect of Temperature, $\mathrm{NaOH}$ Addition, and Pressure on $\mathrm{pH}$ and Electrical Conductivity}

The $\mathrm{pH}$ of the DSW, which ranged from 7.9 to 8.7 (Table 1), was adjusted to the $\mathrm{pH}$ of the set-points established at 8.7, 9.5, and 11 (Table 3). Higher values of the DSW pH meant higher values of the concentrate $\mathrm{pH}$, due to the membranes' high $\mathrm{OH}^{-}$rejection when adding $\mathrm{NaOH}$, while the $\mathrm{pH}$ of the permeate remained constant.

Figure 2 shows the EC of the feed, permeate, and concentrate flows for each test. The $\mathrm{EC}$ of the feed water ranged from 0.6 to $1.1 \mathrm{dS} / \mathrm{m}$, and regardless of the $\mathrm{pH}$, temperature, or pressure, the $\mathrm{RO}$ process decreased the $\mathrm{EC}$ of the permeate to an average steady value of $0.04 \mathrm{dS} / \mathrm{m}$. Similarly, for any $\mathrm{pH}$, the EC of the concentrate increased with the pressure at an average rate of $0.35 \mathrm{dS} / \mathrm{m} / \mathrm{bar}$ and had an average of $5 \mathrm{dS} / \mathrm{m}$. However, the EC of the concentrate increased with the temperature, as a rise of temperature in the feed water diminished the RO salt rejection efficiency, as previously reported [29]. Similar results were found by Cengeloglu et al. and Volkan-Duman and Özmetin [30,31]. This temperature dependence is sometimes referred to as retrograde or inverse solubility, and exists when a dissolution of salts is exothermic; this can be explained because, according to Le Chatelier's principle, extra heat will cause the equilibrium for an exothermic process to shift towards the reactants $[24,25]$.

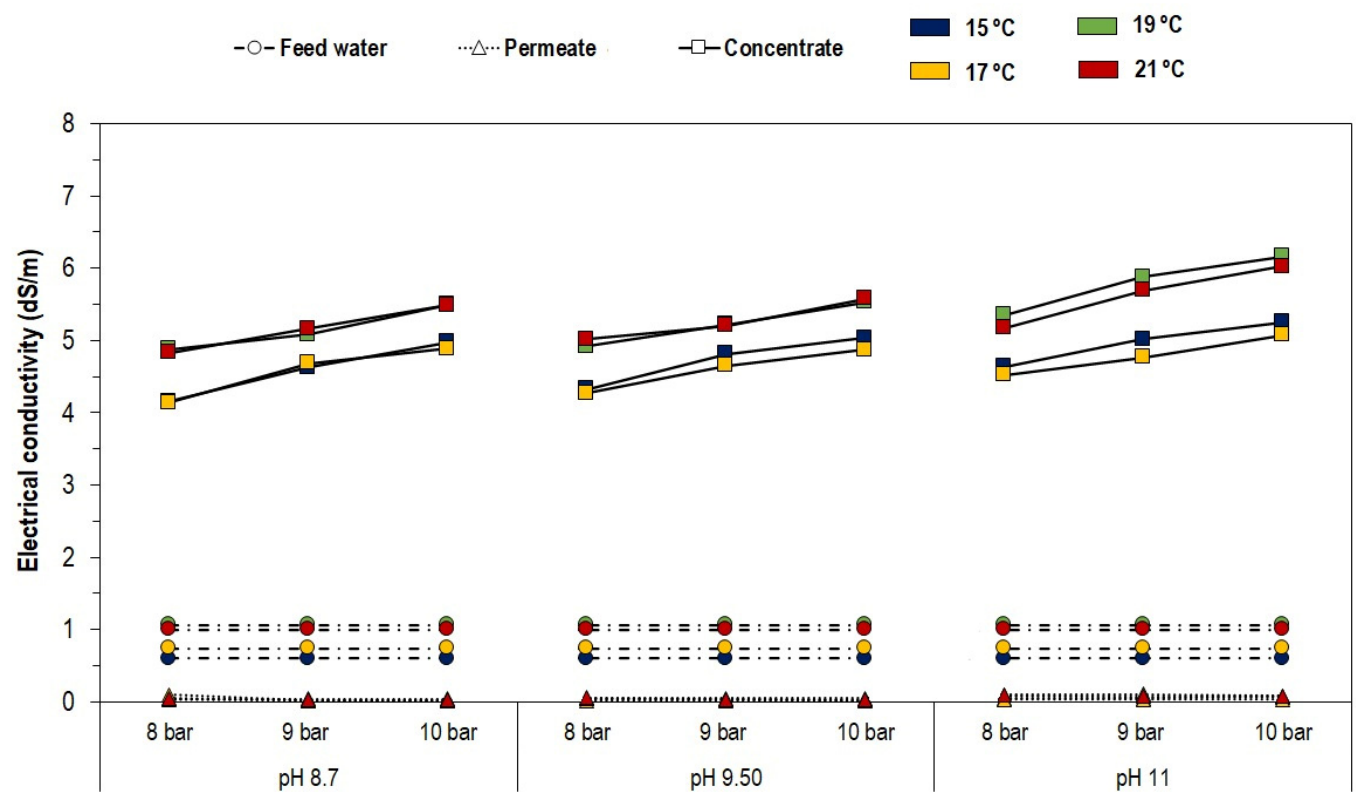

Figure 2. Electrical conductivity of the feed water, permeate, and concentrate flows in the tests performed. 


\subsection{Effect of Temperature, $\mathrm{pH}$, and Pressure on Ion Rejection}

The ion concentrations in the feed water and permeate flows are shown in Figure 3. The feed water mostly had $\mathrm{Cl}^{-}$and $\mathrm{Na}^{+}$, since seawater has $55 \% \mathrm{Cl}^{-}$and $31 \% \mathrm{Na}^{+}$solute content [36]. Lower DSW temperatures reduced the $\mathrm{Cl}^{-}$and $\mathrm{Na}^{+}$concentrations in the feed water as the solubility of salts usually grows with temperature [6,16,24,25]. More specifically, $\mathrm{Cl}^{-}$and $\mathrm{Na}^{+}$increased from 184 and $112 \mathrm{mg} / \mathrm{L}$ to 298 and $170 \mathrm{mg} / \mathrm{L}$, respectively, when the feed water temperature was increased from 15 to $21^{\circ} \mathrm{C}$. However, the rest of the ions $\left(\mathrm{K}^{+}, \mathrm{Ca}^{2+}, \mathrm{Mg}^{2+}, \mathrm{NO}_{3}{ }^{-}, \mathrm{PO}_{4}{ }^{3-}\right.$, and $\left.\mathrm{SO}_{4}{ }^{2}\right)$ remained, to a certain extent, constant to temperature and $\mathrm{pH}$ variations during the tests; this circumstance was attributed to their much lower concentrations (Figure 3). Consequently, the various results at different temperatures of ion rejection in Figure 3 should be interpreted considering the variation of inlet ion concentrations, particularly in the dominant ions $\mathrm{Cl}^{-}$and $\mathrm{Na}^{+}$.

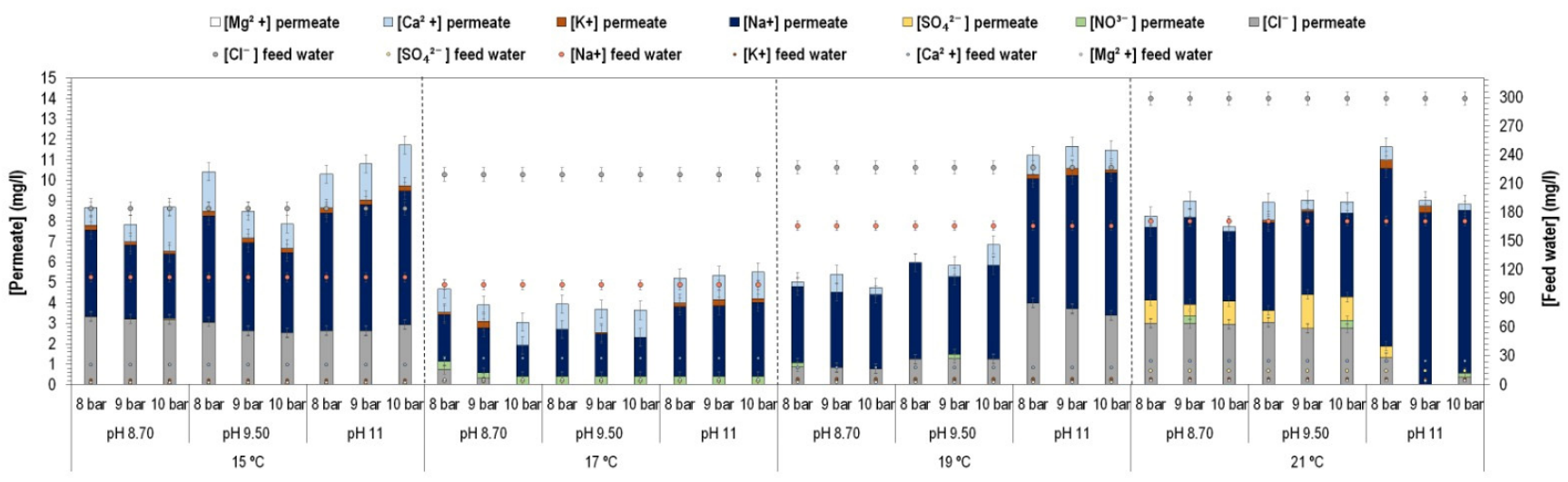

Figure 3. Ion concentrations in the feed water and the permeate flows.

Figure 3 and Table 5 show that, as expected, the permeate had notably reduced concentrations of all ions. The reductions ranged from 79 to $100 \%$, except for boron, which varied between 48 and 99\% (Table 5). The highest concentrations in the permeate, albeit with much lower values than their concentrations in the feed water, were found for $\mathrm{Cl}^{-}$ $(0-4 \mathrm{mg} / \mathrm{L})$ and $\mathrm{Na}^{+}(1.5-8.69 \mathrm{mg} / \mathrm{L})$. Additionally, the presence of $\mathrm{Na}^{+}$was strongly related to the $\mathrm{NaOH}$ added to increase the feed water $\mathrm{pH}$ up to the established set-points (Table 3). It can be observed in Figure 3 that the pressure had a reduction effect on their concentration, except for experiments with $\mathrm{pH}=11$, in which the addition of $\mathrm{NaOH}$ seemed to interact with the rest of the ions and masked that effect. In contrast, the water temperature and $\mathrm{pH}$ did not seem to have any overall effect on the resulting ion concentrations.

Table 5. Rejection rate (\%) in the permeate flow.

\begin{tabular}{cccc}
\hline Ion. & Rejection Rate (\%) & Ion & Rejection Rate (\%) \\
\hline $\mathrm{Ca}^{2+}$ & $90.9-100 \%$ & $\mathrm{NO}_{3}{ }^{-}$ & $79.3-100 \%$ \\
$\mathrm{Cl}^{-}$ & $97.9-100 \%$ & $\mathrm{PO}_{4}{ }^{3-}$ & $79.8-100 \%$ \\
$\mathrm{~K}^{+}$ & $94.1-100 \%$ & $\mathrm{SO}_{4}{ }^{2-}$ & $95.1-100 \%$ \\
$\mathrm{Mg}^{2+}$ & $100 \%$ & $\mathrm{~B}^{3+}$ & $48.5-99.1 \%$ \\
$\mathrm{Na}^{+}$ & $95.2-98.6 \%$ & - & - \\
\hline
\end{tabular}

The concentration of ions in the concentrate flow (vs. the feed water) is shown in Figure A2 (Appendix C). A high concentration of $\mathrm{Cl}^{-}$and $\mathrm{Na}^{+}$was observed in the concentrate (between 1700 and $3327 \mathrm{mg} / \mathrm{L}$ ) and, as in the case of the permeate, the water temperature and the $\mathrm{pH}$ seemed to have no effect on the ion concentrations. However, for most tests, increasing the operating pressure led to higher concentrations of $\mathrm{Cl}^{-}$and $\mathrm{Na}^{+}$ in the concentrate. 


\subsection{Effect of Temperature, $p H$, and Pressure on Boron Rejection}

The boron reduction efficiency of the studied system and the influence of temperature, $\mathrm{pH}$, and pressure are shown in Figure 4. The results show that the tested system is able to reduce boron concentration to below the toxicity threshold of woody (sensitive) crops, but that the efficacy of the system is highly dependent on the feed water $\mathrm{pH}$.

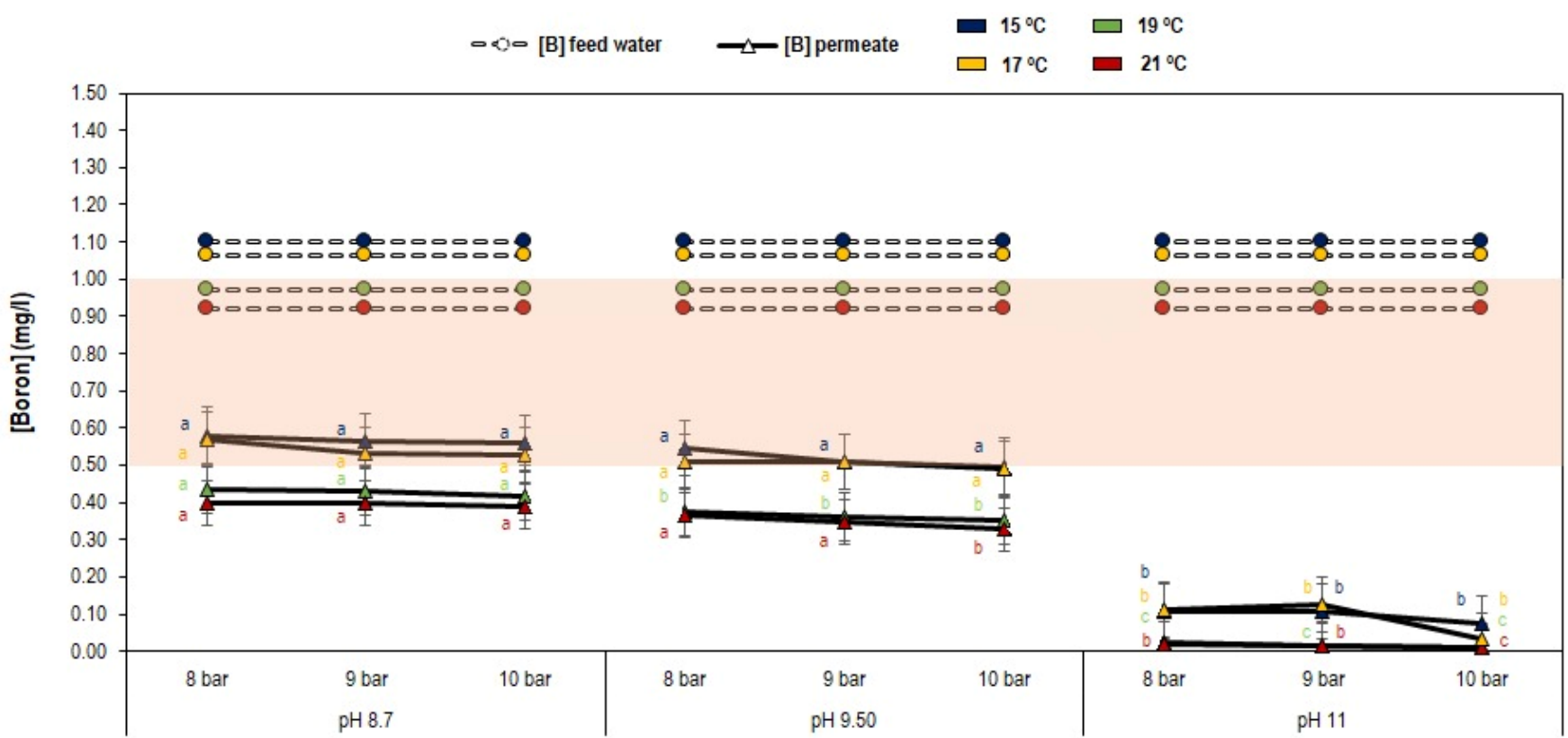

Figure 4. Effect of temperature, $\mathrm{pH}$, and pressure on boron removal. The shaded area represents the phytotoxicity threshold of woody crops. Colored letters indicate the significant differences $(p<0.05)$ at each feed water temperature and operating pressure for the different $\mathrm{pH}$ values.

Lower boron concentrations in the feed water (at 19 and $21^{\circ} \mathrm{C}$ ), also presented lower boron concentrations in the permeate, regardless of the water temperature, with a stable $\mathrm{B}_{\text {feed water }} / \mathrm{B}_{\text {permeate }}$ ratio. This was also observed by Cengeloglu et al. [31], who demonstrated that boron reduction did not mainly depend on the feed water concentration per se, but on the boron rejection capacity of the membranes and their interactions with other parameters. It is hence very likely that the operating conditions in the Escombreras plant were somewhat different in 2021, leading to higher boron concentrations in the DSW, regardless of the seawater temperature (Table 1). A low dependence of boron rejection on the concentration was also observed by Magara et al. [17] for boron concentrations lower than $35 \mathrm{mg} / \mathrm{L}$. Additionally, it should be noted that the range of temperatures in this study was $15-21^{\circ} \mathrm{C}$, since previous research has shown increases in the boron concentration when the feed water was heated from 20 to $35^{\circ} \mathrm{C}$ [27] or from 20 to $40^{\circ} \mathrm{C}$ [37].

One of the most remarkable findings was the strong dependence of boron rejection on the feed water $\mathrm{pH}$, with higher $\mathrm{pH}$ leading to substantially higher boron rejections. As the $\mathrm{pH}$ increased, $\mathrm{H}_{3} \mathrm{BO}_{3}$ reacted with $\mathrm{H}_{2} \mathrm{O}$ and resulted in the production of $\mathrm{H}_{3} \mathrm{O}^{+}$and $\mathrm{B}(\mathrm{OH})_{4}{ }^{-}$, with the latter becoming dominant at $\mathrm{pH}=11$. In contrast to $\mathrm{H}_{3} \mathrm{BO}_{3}, \mathrm{~B}(\mathrm{OH})_{4}{ }^{-}$ does not easily permeate the pores of $\mathrm{RO}$ membranes, and thus the boron rejection increases [31]. In our study, increasing the $\mathrm{pH}$ from 8.7 to 9.5 increased boron reduction by $16.3 \%$ (boron reduction between 50 and $63 \%$ ), while increasing the $\mathrm{pH}$ from 9.5 to 11 increased the boron reduction by 79-97\% (boron reduction between 90 and $99 \%$; boron concentrations between $0-0.12 \mathrm{mg} / \mathrm{L}$ in the permeate, Figure 4). This was in agreement with several previous research studies $[6,15,20]$, where the authors pointed out that boron can be effectively and totally removed when the feed water $\mathrm{pH}$ is close to $11[17,33]$. This occurrence is ruled by the dissociation of boric acid into borate ion as the $\mathrm{pH}$ increases, especially above $\mathrm{pH}=10$, which facilitates the adsorption of boron by the membranes $[12,17,19,20]$. 
Although an increase in $\mathrm{pH}$ level achieves a considerable rejection of boron, the addition of $\mathrm{NaOH}$ may reduce the performance and durability the $\mathrm{RO}$ membranes. This is due to the formation and precipitation of $\mathrm{CaCO}_{3}$, which produces fouling of the membranes and may compromise the salts' adsorption capacity $[8,22,23]$. In addition, it must be noted that the high alkalinity of the permeate means that additional (nitric and phosphoric) acids are needed to subsequently adjust the $\mathrm{pH}$ of the irrigation water, incurring extra costs.

Concerning pressure, some studies have reported that an increase in the operating pressure may enhance the boron reduction. This is the case of Cengeloglu et al. [31], who increased the boron rejection by $12 \%$ when augmenting the operating pressure from 16 to 36 bar, or that of Koseoglu et al. and Lee et al. [33,37] who reported a boron rejection close to $99 \%$ when the operating pressure reached 50 bar. Considering the low range of pressure values of the on-farm system in the study (8-10 bar), it was to be expected that substantial differences were not found (Figure 4).

\subsection{Effect of Temperature, $p H$, and Pressure on Permeate, Concentrate, and Specific Energy}

Figure 5 provides a clear overview of the benefits of higher temperature and $\mathrm{pH}$ values even for the relatively low-pressure range of the trial. At much higher operating pressures (between 79 and 83 bar), Sassi and Mujtaba [27] found increases of permeate flow of $4.0 \%$ and $5.4 \%$, when increasing the temperature of the feed water from 20 to 25 and $35^{\circ} \mathrm{C}$, respectively. In our case, increasing the temperature from 15 to 17,19 , and $21^{\circ} \mathrm{C}$ increased the permeate flow by $2.3 \%, 8.3 \%$, and $20.5 \%$, respectively, for an intermediate scenario of $\mathrm{pH}(9.5)$ and pressure $(9 \mathrm{bar})$. Another positive effect was that the specific energy consumption was notably reduced. Average reductions in specific energy of $0.21 \mathrm{~kW} \cdot \mathrm{h} / \mathrm{m}^{3}$ were observed when the temperature varied from 15 to $21^{\circ} \mathrm{C}$. The higher pressure further forced water to pass through the membranes, obtaining a higher volume of permeate with reduced boron concentration. Although higher pressures increased the energy consumption (data not shown), the specific energy remained constant between 1.30 and $1.58 \mathrm{~kW} \cdot \mathrm{h} / \mathrm{m}^{3}$. These values were somewhat lower than those observed at coastal desalination plants (between 3.5 and $4.3 \mathrm{~kW} \cdot \mathrm{h} / \mathrm{m}^{3}$ ) [38], since the feed water pressures were also much lower. The $\mathrm{pH}$ of the feed water did not affect the permeate or the concentrate flows [27], but it did affect the boron concentration.

\subsection{On-Farm Reverse Osmosis Economic Cost}

The costs of the studied on-farm boron reduction system (D1) and analogous systems with higher flows (D2 and D3) are summarized in Figure 6. The costs correspond to the intermediate scenario: $\mathrm{pH}=9.5$ and pressure $=9$ bar, which was observed to reduce the boron concentration below the toxic threshold for woody crops in D1 (Figure 4).

The depreciation costs depended mainly on the type of membrane selected and on the scale of the equipment $[18,39]$. In this sense, D1 showed a depreciation cost of $0.626 \mathrm{EUR} / \mathrm{m}^{3}$ (4820 EUR/year), whereas the other two designs, D2 and D3, showed lower depreciation costs of $0.053 \mathrm{EUR} / \mathrm{m}^{3}$ (7791 EUR/year) and $0.046 \mathrm{EUR} / \mathrm{m}^{3}$ (13,524 EUR/year), respectively. The reagent costs were principally influenced by the amount of $\mathrm{NaOH}$ needed to increase the $\mathrm{pH}$ of the feed water (see calculation details in Appendix A) for each test. Reagent costs were $0.140 \mathrm{EUR} / \mathrm{m}^{3}(1078,20,580$, and 41,160 EUR/year for D1, D2, and D3, respectively). The maintenance costs decreased from $0.110 \mathrm{EUR} / \mathrm{m}^{3}$ (847 EUR/year) in the case of D1 to $0.07 \mathrm{EUR} / \mathrm{m}^{3}$ (20,580 EUR/year) in the case of D3. The energy cost was also substantially higher for D1 $\left(0.20 \mathrm{EUR} / \mathrm{m}^{3}\right)$ but higher operating flows could diminish it by $33 \%$ and $38 \%$ for D2 $\left(0.12 \mathrm{EUR} / \mathrm{m}^{3}\right)$ and D3 $\left(0.11 \mathrm{EUR} / \mathrm{m}^{3}\right)$, respectively. This is important, as the energy cost of boron reduction can represent between 25 and $45 \%$ of the total operating costs [27]. In our study, the energy cost in D1 represented only $18.6 \%$ of the total costs since lower permeate flows required less energy. In summary, the total costs were $1.076 \mathrm{EUR} / \mathrm{m}^{3}$ (= 8285.2 EUR/year), $0.326 \mathrm{EUR} / \mathrm{m}^{3}$ (= 47,922 EUR/year), and $0.307 \mathrm{EUR} / \mathrm{m}^{3}$ (= 90,258 EUR/year) for D1, D2, and D3, respectively, highlighting the importance of scaling up results to a commercial size. In particular, the depreciation costs 
represented $58.1 \%$ of the total costs in D1, yet only $16.2 \%$ and $14.9 \%$ in the case of the D2 and D3 plants (Figure 6). In fact, the specific cost for reducing boron at coastal desalination plants, rather than at the farm, has been estimated at much lower values, between 0.02 and $0.12 \mathrm{EUR} / \mathrm{m}^{3}[5,6,40,41]$.

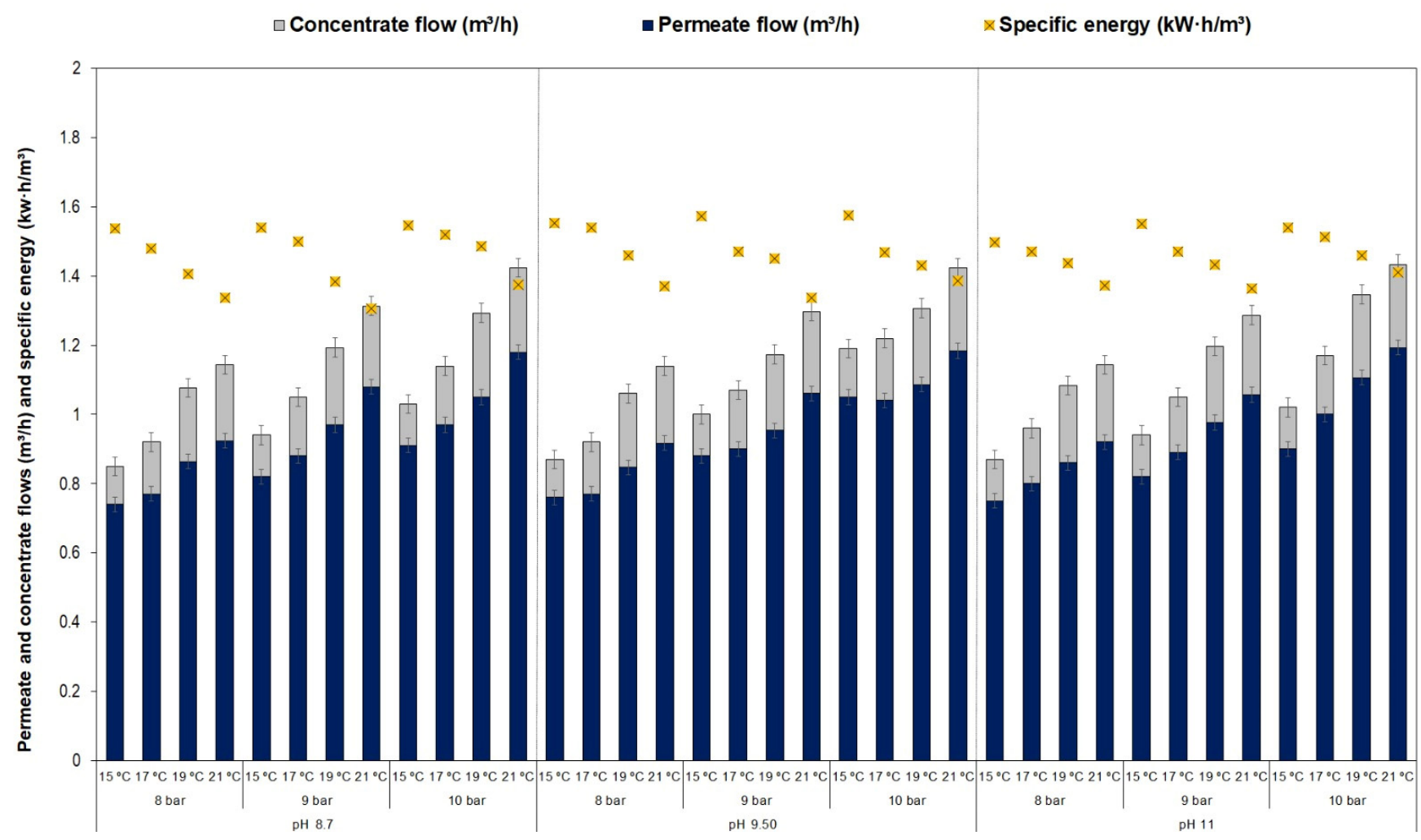

Figure 5. Effect of the temperature $\left({ }^{\circ} \mathrm{C}\right)$, the $\mathrm{pH}$, and the pressure (bar) on the permeate and the concentrate flows $\left(\mathrm{m}^{3} / \mathrm{h}\right)$ and the specific energy $\left(\mathrm{kW} \cdot \mathrm{h} / \mathrm{m}^{3}\right)$.

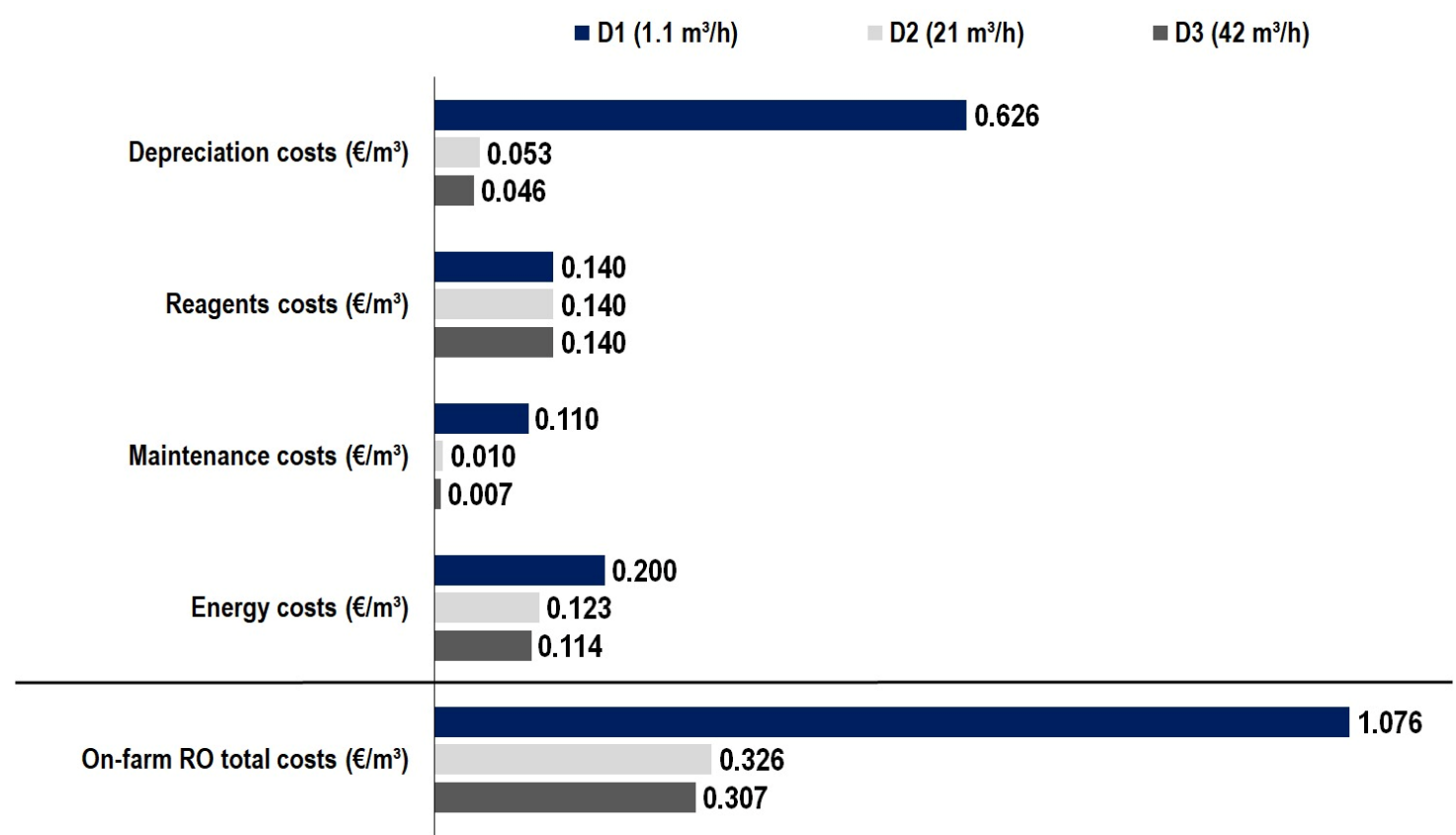

Figure 6. Depreciation and specific operating costs for D1, D2, and D3 boron removal systems. 
When comparing our results with previous research, we found even higher specific costs for reducing boron. For example, Sassi and Mujtaba [27] studied the reduction of boron by simulating a two-stage RO process with a feed boron concentration of $5 \mathrm{mg} / \mathrm{L}$ and estimated specific costs at between 0.72 and $0.89 \mathrm{EUR} / \mathrm{m}^{3}$, for a permeate flow of $95 \mathrm{~m}^{3} / \mathrm{h}$, similar to the cost estimated for D1. Other studies that evaluated high boronrejecting seawater $\mathrm{RO}$ membrane systems with feed boron concentration between 5 and $7.5 \mathrm{mg} / \mathrm{L}$ and permeate flows around $250 \mathrm{~m}^{3} / \mathrm{h}$ obtained similar values $\left(0.40 \mathrm{EUR} / \mathrm{m}^{3}\right.$ and $0.48 \mathrm{EUR} / \mathrm{m}^{3}$, respectively) as those calculated for D2 and D3 [18,42,43]. Much higher specific costs (around 2.8 EUR $/ \mathrm{m}^{3}$ ) were reported for a plant with a production capacity of $0.22 \mathrm{~m}^{3} / \mathrm{h}$, despite the lower boron concentration in the feed water used (between 1.3 and $2.2 \mathrm{mg} / \mathrm{L}$ ) [18]. These higher values could be related to a lower specificity for boron rejection of the membranes used.

\section{Conclusions}

This work has assessed the technical and economic viability of performing boron removal with a novel on-farm $R O$ system with a flow capacity of $1.1 \mathrm{~m}^{3} / \mathrm{h}$, which operates at low pressures and high alkalinity of the feed water in order to achieve a boron concentration below the threshold of sensitive crops $(0.5 \mathrm{mg} / \mathrm{L})$. The motivation of the work was the fact the farmers may receive DSW with boron concentrations close to $1 \mathrm{mg} / \mathrm{L}$. Although coastal desalination plants operating at high pressures could implement processes to reduce boron below $0.5 \mathrm{mg} / \mathrm{L}$ without inlet water inlet being highly alkalized, in some countries like Spain such processes are not yet implemented. The reason for this, is that boron concentrations up to $1 \mathrm{mg} / \mathrm{L}$ are legal and that it would imply an increase of costs of the product water.

The technical viability of the system has been evaluated at pressures from 8 to 10 bar, with $\mathrm{pH}$ values between 8.7 and 11 , and at temperatures from 15 to $21^{\circ} \mathrm{C}$. When the DSW feed water passed through the RO membranes all ions were reduced, but only boron was observed to be affected by the operating conditions. An increase in the feed water $\mathrm{pH}$ notably increased the boron reduction, achieving almost total boron depletion when augmenting $\mathrm{pH}$ values from 8.7 to 11 (rejections from $50 \%$ to $99 \%$ ). Although the tested increase of the feed water temperature and pressure did not directly improve boron removal, they did increase the total permeate flow as far as a $20.5 \%\left(15^{\circ} \mathrm{C}\right.$ to $\left.21{ }^{\circ} \mathrm{C}\right)$ and notably reduced specific energy consumption with an average lessening of $0.21 \mathrm{~kW} \cdot \mathrm{h} / \mathrm{m}^{3}$.

To evaluate the economic feasibility of the system, the costs were estimated for intermediate operating conditions with $\mathrm{pH}=9.5$ and pressure $=9$ bar, which was observed to reduce the boron concentration below the toxic threshold for sensitive crops. For this case, the total costs of boron removal were estimated at $1.076 \mathrm{EUR} / \mathrm{m}^{3}$, which would likely be unaffordable for most crops. Considering that the depreciation costs of the equipment represented $58.1 \%$ of the total, the results were scaled up to commercial sizes to get a more realistic estimation of costs. For commercial capacities of 21 and $42 \mathrm{~m}^{3} / \mathrm{h}$, the costs fell to $0.326 \mathrm{EUR} / \mathrm{m}^{3}$ and $0.307 \mathrm{EUR} / \mathrm{m}^{3}$, respectively, with depreciation costs representing only $16.2 \%$ and $14.9 \%$. However, it is important to highlight that these values still exceed the reported cost of boron removal at coastal desalination plants $\left(0.02-0.12 \mathrm{EUR} / \mathrm{m}^{3}\right)$.

The results presented in this article provide novel guidance on the feasibility of implementing on-farm boron removal RO systems, when DSW is provided by coastal plants with boron concentrations above the crop tolerance. However, further research is needed to assess how high alkalinity may reduce the performance and durability of the $\mathrm{RO}$ membranes and the costs incurred by the need of additional products to adjust the $\mathrm{pH}$ of the irrigation water. In addition, apart from RO systems, other alternative systems like cation exchange resins could be implemented at the farm scale and may achieve better technical and/or economic performance.

Author Contributions: System mounting, J.F.M.-V., R.M.-d.-T., F.J.J.-C. and B.M.-G.; tests and data acquisition, J.F.M.-V., R.M.-d.-T., F.J.J.-C., A.I.-M. and V.M.-A.; data interpretation, J.F.M.-V., A.I.-M. and B.G.-E.; writing—original draft preparation, J.F.M.-V. and A.I.-M.; writing—review and editing, 
J.F.M.-V., A.I.-M., B.G.-E. and V.M.-A.; project administration, J.F.M.-V.; funding acquisition, J.F.M.-V. and R.M.-d.-T. All authors have read and agreed to the published version of the manuscript.

Funding: This study was supported by the Ministry for Science and Innovation (MCIN, Spain), the State Research Agency (AEI, Spain) and the European Regional Development Fund (ERDF, EU) under the project SEARRISOST (RTC-2017-6192-2). Imbernón-Mulero acknowledges the support for his PhD work from the project SEA4CROP (MCIN/AEI/PID2020-118492RA-C22) and the predoctoral program of the Technical University of Cartagena (RV-484/21, UPCT, Spain). Gallego-Elvira acknowledges the support from The Ministry of Science, Innovation and University of Spain ("Beatriz Galindo" Fellowship BEAGAL18/00081).

Institutional Review Board Statement: Not applicable.

Informed Consent Statement: Not applicable.

Data Availability Statement: Not applicable.

Acknowledgments: The collaboration of Catedra Trasvase y Sostenibilidad-Jose Manuel Claver Valderas is acknowledged.

Conflicts of Interest: The authors declare no conflict of interest.

\section{Appendix A}

This appendix presents the calculations to obtain the volume of $\mathrm{NaOH}$ to be added to the input DSW in treatments 2 and 3 to reach the $\mathrm{pH}$ set-points. The $\mathrm{NaOH}$ solution $(50 \mathrm{~L})$ contains $49 \mathrm{~L}$ of DSW and $1 \mathrm{~L}$ of $\mathrm{NaOH}_{50 \%}$ (50\% purity). The density of $\mathrm{NaOH}_{50 \%}($ d) is $1.52 \mathrm{~kg} / \mathrm{L}$. To determine the volumes of $\mathrm{NaOH}$ to be added to the input DSW to reach the $\mathrm{pH}$ set-points, we followed the following process:

1. Determination of the solution molarity:

$$
M=\frac{N^{\mathrm{o}} \text { mol of solute }}{\text { DSW volume }}
$$

where $M$ is the molarity of the solution in $\mathrm{mol} / \mathrm{l}$.

$$
N^{\mathrm{o}} \text { mol of solute }=\frac{\mathrm{NaOH} \text { mass }}{\mathrm{NaOH} \text { molecular weight }} .
$$

where

$$
\mathrm{NaOH} \text { mass }=R \cdot \mathrm{d}=\frac{50}{100} \cdot 1520=760 \frac{\mathrm{g} \mathrm{NaOH}}{\mathrm{L}} .
$$

where $R(\%)$ represents the solution richness.

Hence,

$$
\begin{gathered}
N^{\mathrm{o}} \text { mol of solute }=\frac{760}{40.01}=18.95 \frac{\mathrm{NaOH} \text { mol }}{\mathrm{L}}, \\
M=\frac{N^{\mathrm{o}} \text { mol of solute }}{\text { DSW volume }}=\frac{18.95}{49 \mathrm{~L} \mathrm{H}_{2} \mathrm{O}}=0.3876 \mathrm{M} .
\end{gathered}
$$

2. Determination of the $\mathrm{NaOH}$ purity of the mixture $\left(49 \mathrm{~L}^{2} \mathrm{H}_{2} \mathrm{O}\right.$ and $1 \mathrm{~L}$ of $\left.\mathrm{NaOH}\right)$ :

$$
\begin{gathered}
49 \mathrm{~L} \mathrm{H}_{2} \mathrm{O} \cdot \frac{1000 \mathrm{~g}}{1 \mathrm{~L}}+1 \mathrm{~L} \mathrm{NaOH} \cdot \frac{1520 \mathrm{~g}}{1 \mathrm{~L}}=50,520 \mathrm{~g}, \\
\frac{760}{50,520} \cdot 100=1.5 \% .
\end{gathered}
$$

3. Determination of the amount of solution of $0.3876 \mathrm{M}$ and $1.5 \%$ purity $\mathrm{NaOH}$ to be injected to reach the different $\mathrm{pH}$ set-points:

$$
\mathrm{H}_{2} \mathrm{O}+\mathrm{NaOH} \rightarrow \mathrm{Na}^{+}+\left[\mathrm{OH}^{-}\right]+\mathrm{H}_{2} \mathrm{O} .
$$


4. Determination of the amount of solution of $0.3876 \mathrm{M}$ and $1.5 \%$ purity $\mathrm{NaOH}$ to be injected to reach the different $\mathrm{pH}$ set-points:

$$
\begin{gathered}
p O H=14-p H_{o b j}=-\log \left[\mathrm{OH}^{-}\right], \\
-14+p H_{o b j}=\log \left[\mathrm{OH}^{-}\right], \\
{\left[\mathrm{OH}^{-}\right]=10^{\left(-14+p H_{o b j}\right)}=X,}
\end{gathered}
$$

where $\mathrm{pOH}$ is the concentration of hydroxyl ions in a solution and $p \mathrm{H}_{o b j}$ is the $\mathrm{pH}$ objective in the solution.

5. Determination of the $\mathrm{NaOH}$ solution volume of $1.5 \%$ to inject depending on the pHobj:

$$
\begin{gathered}
M_{R 1.5 \%}=0.3876=\frac{N^{\mathrm{o}} \mathrm{mol} \text { of solute }}{V_{R 1.5 \%}}, \\
N^{\mathrm{o}} \mathrm{mol} \text { of solute }=V_{R 1.5 \%} \cdot 0.3876, \\
M=\frac{V_{R 1.5 \%} \cdot 0.3876}{V_{R 1.5 \%}+V_{\text {Treated }}}=X, \\
V_{R 1.5 \%}=\frac{X \cdot V_{\text {Treated }}}{0.3876-X^{\prime}}
\end{gathered}
$$

where $M_{R 1.5 \%}$ is the molarity of the $\mathrm{NaOH}$ solution at $1.5 \%, V_{\text {Treated }}(\mathrm{L})$ is the volume to be alkalized during the process, i.e., the volume of permeate + the volume of concentrate, and $V_{R 1.5 \%}(\mathrm{~L})$ is the volume of the $1.5 \% \mathrm{NaOH}$ solution to be injected and $X$ the $\left[\mathrm{OH}^{-}\right]$or $[\mathrm{NaOH}]$.

6. Determination of the exponential regression to determine the volume of $\mathrm{NaOH}$ per volume of treated water from the $\mathrm{pH}_{o b j}$ :

$$
V_{R 1.5 \%} / V_{\text {Treated }}=\frac{\left(10^{\left(-14+p H_{o b j}\right)}\right)}{\left(0.3876-10^{\left(-14+p H_{o b j}\right)}\right)} .
$$

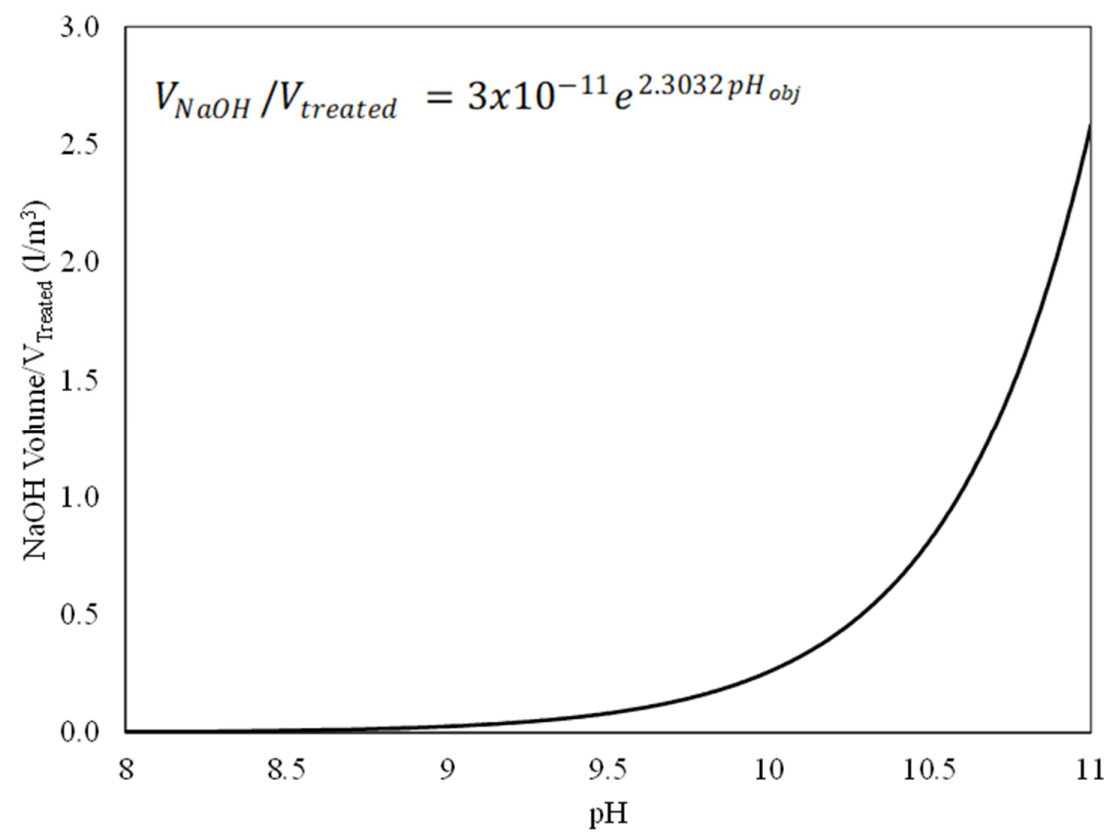

Figure A1. Volume of $\mathrm{NaOH}$ required to increase the $\mathrm{pH}$ of the feed water to $p H_{o b j}$. 


\section{Appendix B}

Appendix B shows the calculations to obtain the volume of antiscalant (Genesys LF) to be added to the input DSW. The antiscalant solution $(50 \mathrm{~L})$ contains $49 \mathrm{~L}$ of DSW and $1 \mathrm{~L}$ of Genesys $L F$ with a density of $1.34 \mathrm{~kg} / \mathrm{L}$. It has been estimated that the injector has a maximum capacity of $6 \mathrm{~L} / \mathrm{h}$ and it is regulated at $25 \%(1.5 \mathrm{~L} / \mathrm{h})$. It is also assumed that the equipment produces $1 \mathrm{~m}^{3} / \mathrm{h}$ of permeate. To determine the volume of Genesys $L F$ to be added to the input DSW we followed the following process:

$$
\begin{gathered}
49 \mathrm{~L} \mathrm{H}_{2} \mathrm{O} \cdot \frac{1000 \mathrm{~g}}{1 \mathrm{~L}}+1 \mathrm{~L} \text { Genesys LF } \frac{1340 \mathrm{~g}}{1 \mathrm{~L}}=50,340 \mathrm{~g}, \\
1.5 \frac{\mathrm{L}}{\mathrm{h}} \cdot \frac{2}{100}=0.03 \frac{\mathrm{L} \text { Genesys LF }}{\mathrm{h} \cdot \mathrm{m}^{3} \text { Permeated }} \\
0.03 \frac{\mathrm{L} \text { Genesys LF }}{\mathrm{h} \cdot \mathrm{m}^{3} \text { Permeated }} \cdot \frac{1.34 \mathrm{~kg}}{1 \mathrm{~L}}=40.2 \frac{\mathrm{g} \text { Genesys LF }}{\mathrm{h} \cdot \mathrm{m}^{3} \text { Permeated }}
\end{gathered}
$$

Appendix C

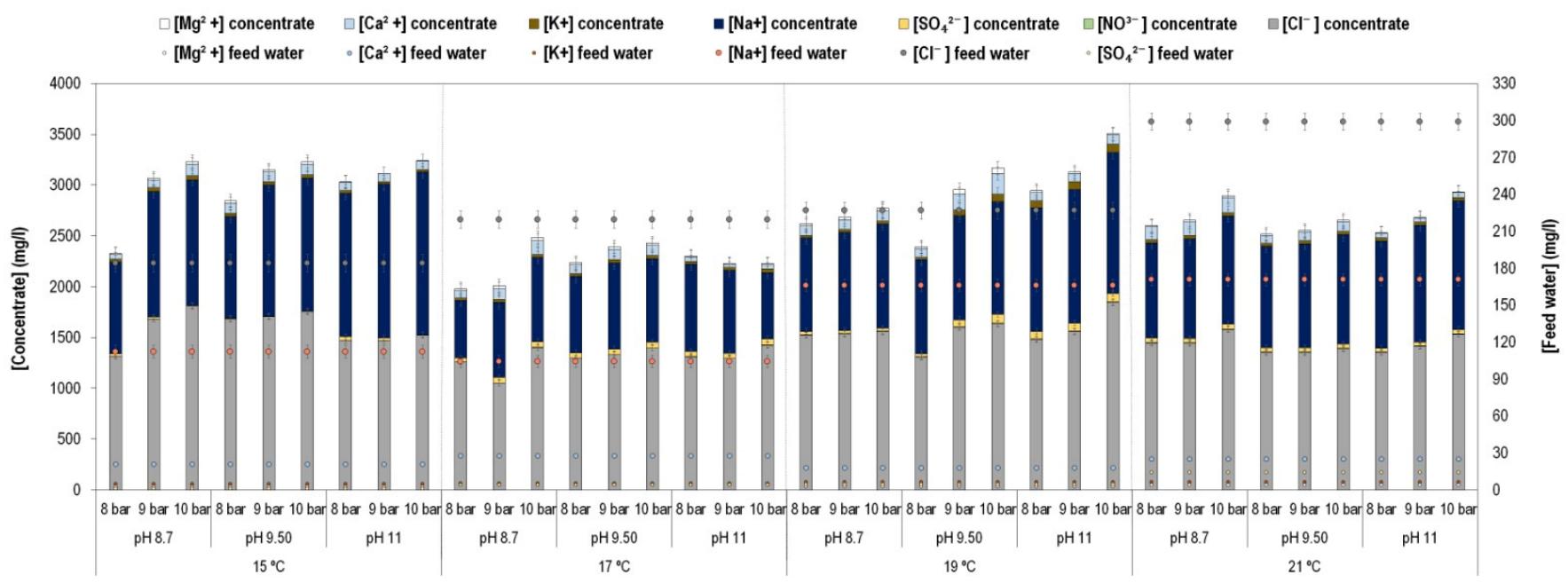

Figure A2. Ion concentrations in the feed water and the concentrate flow. 


\section{Appendix D}

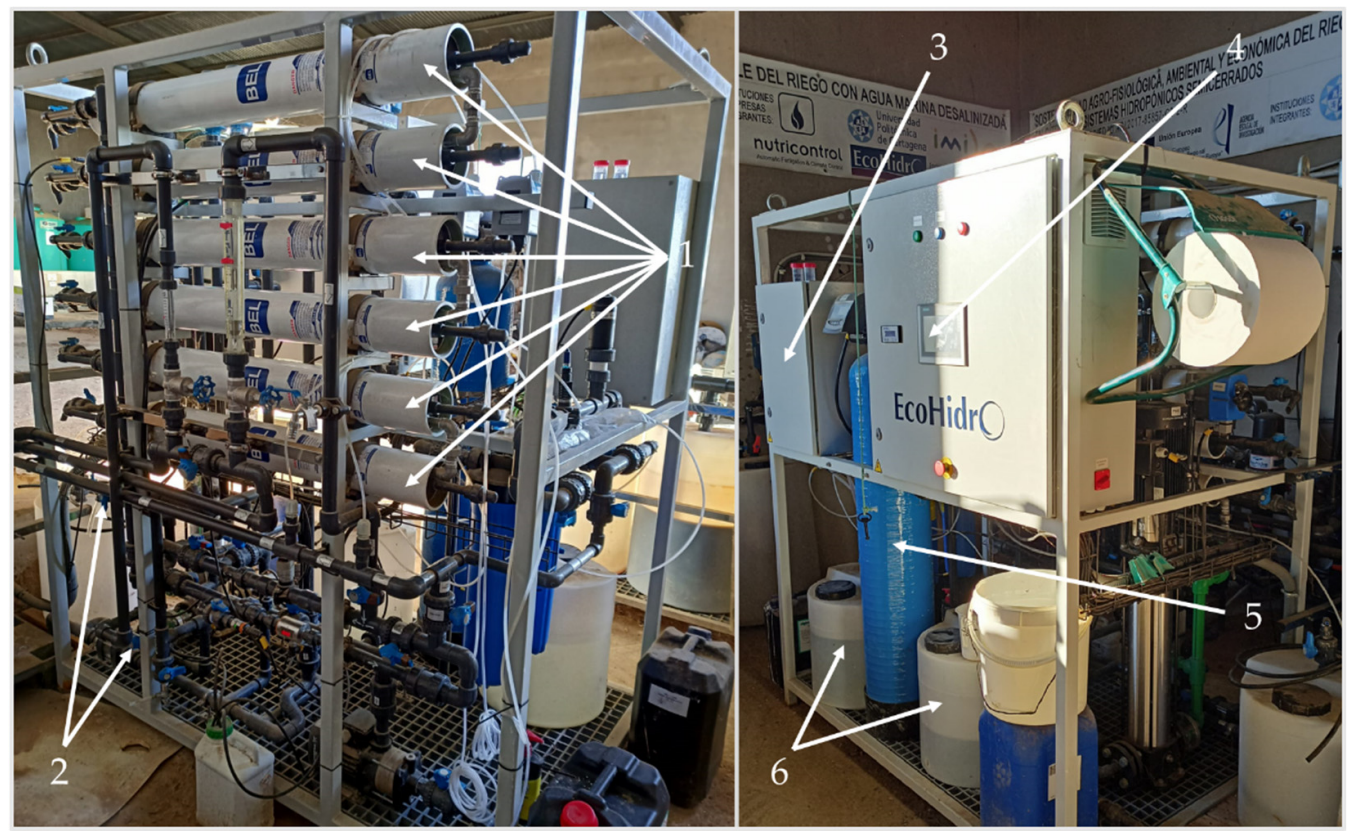

Figure A3. Experimental on-farm reverse osmosis system. (1) RO membranes; (2) sampling (permeate and concentrate) point; (3) injector panel; (4) system control panel; (5) zeolite and pyrolusite bed filter; (6) $\mathrm{NaOH}$ and antiscalant tanks.

\section{References}

1. Jones, E.; Qadir, M.; van Vliet, M.T.; Smakhtin, V.; Kang, S.M. The state of desalination and brine production: A global outlook. Sci. Total Environ. 2019, 657, 1343-1356. [CrossRef]

2. Najid, N.; Fellaou, S.; Kouzbour, S.; Gourich, B.; Ruiz-García, A. Energy and environmental issues of seawater reverse osmosis desalination considering boron rejection: A comprehensive review and a case study of exergy analysis. Process Saf. Environ. Prot. 2021, 156, 373-390. [CrossRef]

3. March, H.; Saurí, D.; Rico-Amorós, A. The end of scarcity? Water desalination as the new cornucopia for Mediterranean Spain. The end of scarcity? Water desalination as the new cornucopia for Mediterranean Spain. J. Hydrol. 2014, 519, 2642-2651. [CrossRef]

4. Martínez-Álvarez, V.; Maestre-Valero, J.F.; González-Ortega, M.J.; Gallego-Elvira, B.; Martín-Gorriz, B. Characterization of the Agricultural Supply of Desalinated Seawater in Southeastern Spain. Water 2019, 11, 1233. [CrossRef]

5. Borokhov-Akerman, E.; Simhon, M.V.; Gitis, V. Advanced treatment options to remove boron from seawater. Desalination Water Treat. 2012, 46, 285-294. [CrossRef]

6. Rodriguez-Pastor, M.; Ruiz, A.M.; Chillon, M.F.; Rico, D.P. Influence of $\mathrm{pH}$ in the elimination of boron by means of reverse osmosis. Desalination 2001, 140, 145-152. [CrossRef]

7. Propuesta de Proyecto de Plan Hidrológico de la Demarcación Hidrográfica del Segura—Revisión del Tercer Ciclo. Available online: www.chsegura.es/export/sites/chs/descargas/planificacionydma/planificacion21-27 (accessed on 14 November 2021).

8. Tu, K.L.; Chivas, A.R.; Nghiem, L.D. Effects of membrane fouling and scaling on boron rejection by nanofiltration and reverse osmosis membranes. Desalination 2011, 279, 269-277. [CrossRef]

9. Gorenflo, A.; Brusilovsky, M.; Faigon, M.; Liberman, B. High pH operation in seawater reverse osmosis permeate: First results from the world's largest SWRO plant in Ashkelon. Desalination 2007, 203, 82-90. [CrossRef]

10. García-Sánchez, F.; Simón-Grao, S.; Martínez-Nicolás, J.J.; Alfosea-Simón, M.; Liu, C.; Chatzissavvidis, C.; Pérez-Pérez, J.G.; Cámara-Zapata, J.C. Multiple stresses occurring with boron toxicity and deficiency in plants. J. Hazard. Mater. 2020, $397,122713$. [CrossRef]

11. Gimeno, V.; Simón, I.; Nieves, M.; Martínez, V.; Cámara-Zapata, J.M.; García-Torres, A.L.; García-Sánchez, F. The physiological and nutritional responses to an excess of boron by Verna lemon trees that were grafted on four contrasting rootstocks. Trees 2012, 26, 1513-1526. [CrossRef]

12. Nadav, N. Boron removal from seawater reverse osmosis permeate utilizing selective ion exchange resin. Desalination 1999, 124, 131-135. [CrossRef]

13. Yoshinari, A.; Takano, J. Insights into the mechanisms underlying boron homeostasis in plants. Front. Plant Sci. 2017, 8, 1951. [CrossRef]

14. Nable, R.O.; Banuelos, G.S.; Paull, J.G. Boron toxicity. Plant Soil 1997, 193, 181-198. [CrossRef] 
15. Kayaci, S.; Tantekin-Ersolmaz, S.B.; Göktuğ-Ahunbay, M.; Krantz, W.B. Technical and economic feasibility of the concurrent desalination and boron removal (CDBR) process. Desalination 2020, 486, 114474. [CrossRef]

16. Freger, V.; Shemer, H.; Sagiv, A.; Semiat, R. Chapter 8-Boron Removal Using Membranes. In Boron Separation Processes; Elsevier: Amsterdam, The Netherlands, 2015; pp. 199-217.

17. Magara, Y.; Tabata, A.; Kohki, M.; Kawasaki, M.; Hirose, M. Development of boron reduction system for sea water desalination. Desalination 1998, 118, 25-33. [CrossRef]

18. Chillón-Arias, M.F.; Valero-i-Bru, L.; Prats-Rico, D.; Varó-Galvañ, P. Approximate cost of the elimination of boron in desalinated water by reverse osmosis and ion exchange resins. Desalination 2011, 273, 421-427. [CrossRef]

19. Rioyo, J.; Aravinthan, V.; Bundschuh, J.; Lynch, M. 'High-pH softening pretreatment' for boron removal in inland desalination systems. Sep. Purif. Technol. 2018, 205, 308-316. [CrossRef]

20. Dydo, P.; Turek, M.; Milewski, A. Removal of boric acid, monoborate and boron complexes with polyols by reverse osmosis membrane. Desalination 2013, 334, 39-45. [CrossRef]

21. Kürklü, S.; Velioğlu, S.; Ahunbay, M.G.; Tantekin-Ersolmaz, S.B.; Krantz, W.B. A novel energy-efficient concurrent desalination and boron removal (CDBR) process. Desalination 2017, 423, 79-94. [CrossRef]

22. Cohen, R.D.; Probstein, R.F. Colloidal fouling of reverse osmosis membranes. J. Colloid Interface Sci. 1986, 114, 194-207. [CrossRef]

23. Lee, S.; Cho, J.; Elimelech, M. Combined influence of natural organic matter (NOM) and colloidal particles on nanofiltration membrane fouling. J. Membr. Sci. 2005, 262, 27-41. [CrossRef]

24. Wang, S.; Zhang, F.; Liu, X.; Zhang, L. CaO solubility and activity coefficient in molten salts $\mathrm{CaCl} 2-\mathrm{x}(\mathrm{x}=0, \mathrm{NaCl}, \mathrm{KCl}, \mathrm{SrCl} 2$, $\mathrm{BaCl} 2$ and $\mathrm{LiCl})$. Thermochim. Acta 2008, 470, 105-107. [CrossRef]

25. Voisin, T.; Erriguible, A.; Ballenghien, D.; Mateos, D.; Kunegel, A.; Cansell, F.; Aymonier, C. Solubility of inorganic salts in suband supercritical hydrothermal environment: Application to SCWO processes. J. Supercrit. Fluids 2017, 120, 18-31. [CrossRef]

26. Hoon, H.; Jae-Hong, K. A mechanistic study on boron rejection by sea water reverse osmosis membranes. J. Membr. Sci. 2006, 286, 269-278.

27. Sassi, K.M.; Mujtaba, I.M. MINLP based superstructure optimization for boron removal during desalination by reverse osmosis. J. Membr. Sci. 2013, 440, 29-39. [CrossRef]

28. Hasson, D.; Shemer, H.; Brook, I.; Zaslavschi, I.; Semiat, R.; Bartels, C.; Wilf, M. Scaling propensity of seawater in RO boron removal processes. J. Membr. Sci. 2011, 384, 198-204. [CrossRef]

29. Escarabajal-Henarejos, D.; Parras-Burgos, D.; Ávila-Dávila, L.; Cánovas-Rodríguez, F.J.; Molina-Martínez, J.M. Study of the Influence of Temperature on Boron Concentration Estimation in Desalinated Seawater for Agricultural Irrigation. Water 2021, 13, 322. [CrossRef]

30. Kabay, N.; Bryjak, M.; Schlosser, S.; Kitis, M.; Avlonitis, S.; Matejka, Z.; Al-Mutaz, I.; Yuksel, M. Adsorption-membrane filtration (AMF) hybrid process for boron removal from seawater: An overview. Desalination 2008, 223, 38-48. [CrossRef]

31. Cengeloglu, Y.; Arslana, G.; Tor, A.; Kocaka, I.; Dursunc, N. Removal of boron from water by using reverse osmosis. Sep. Purif. Technol. 2008, 64, 141-146. [CrossRef]

32. Volkan-Duman, M.; Özmetin, E. Boron removal from waste water originating in the open pit mines of Bigadiç Boron Work by means of reverse osmosis. Int. J. Glob. Warm. 2014, 6, 252-269. [CrossRef]

33. Koseoglu, H.; Kabay, N.; Yüksel, M.; Kitis, M. The removal of boron from model solutions and seawater using reverse osmosis membranes. Desalination 2008, 223, 126-133. [CrossRef]

34. Białek, R.; Mitko, K.; Dydo, P.; Turek, M. Electrodialytic separation of boric and hydrochloric acids. Desalination 2014, 342, 29-34. [CrossRef]

35. Corzo, B.; de la Torre, T.; Sans, C.; Escorihuela, R.; Navea, S.; Malfeito, J.J. Long-term evaluation of a forward osmosis-nanofiltration demonstration plant for wastewater reuse in agriculture. Chem. Eng. J. 2018, 338, 383-391. [CrossRef]

36. Murugaiyan, K.; Sivakumar, K. Seasonal variation in elemental composition of Stoechospermum marginatum (Ag.) Kutz and Sargassum wightii (Greville Mscr.) J.G. Agardh in relation to chemical composition of seawater. Colloids Surf. B Biointerfaces 2008, 64, 140-144. [CrossRef] [PubMed]

37. Lee, C.; Kang, Y.; Kim, D.-H.; Kim, I.S. Practical Considerations of Wastewater-Seawater Integrated Reverse Osmosis: Design Constraint by Boron Removal. Membranes 2021, 11, 240. [CrossRef]

38. Lapuente, E. Full cost in desalination. A case study of the Segura River Basin. Desalination 2012, 300, 40-45. [CrossRef]

39. Soliman, M.N.; Guen, F.; Ahmed, S.; Saleem, H.; Khalil, M.; Zaidi, S. Energy consumption and environmental impact assessment of desalination plants and brine disposal strategies. Process Saf. Environ. Prot. 2021, 147, 589-608. [CrossRef]

40. Glueckstern, P.; Priel, M.; Kotzer, E. Blending brackish water with desalted seawater as an alternative to brackish water desalination. Desalination 2005, 178, 227-232. [CrossRef]

41. Hilal, N.; Kim, G.J.; Somerfield, C. Boron removal from saline water: A comprehensive review. Desalination 2011, 273, 23-35. [CrossRef]

42. Redondo, J.; Busch, M.; De Witte, J.P. Boron removal from seawater using FILMTECTM high rejection SWRO membranes. Desalination 2003, 156, 229-238. [CrossRef]

43. Taniguchi, M.; Fusaoka, Y.; Nishikawa, T.; Kurihara, M. Boron removal in RO seawater desalination. Desalination 2004, 167, 419-426. [CrossRef] 